The Canadian Journal of Higher Education, Vol. XXIV-2, 1994

La revue canadienne d'enseignement supérieur, Vol. XXIV-2, 1994

\title{
Education-Job Mismatch Among Canadian University Graduates: Implications for Employers and Educators*
}

\section{LINDSAY REDPATH}

\section{Abstract}

This paper presents some of the key findings from a recent study of education-job mismatch among a group of Canadian university graduates. It argues that research on this form of underemployment can greatly enhance our knowledge of the changing structure of labour market opportunities and the relationship between education credentials and job skill requirements. In the wake of recent concerns about skill shortages, the education system has borne the brunt of criticism for failing to prepare young people for labour market entry. However, what is perceived as a problem of skills shortages may be more of a problem of inadequate skills utilization, in which case policy responses placing greater onus on employers are warranted.

\section{Résumé}

Cet article rapporte les résultats principaux d'une étude récente traitant de l'inadéquation entre l'éducation des diplômés universitaires et leur place dans le monde du travail. Elle soutient qu'on aurait intérêt à étudier cette forme de sous-emploi afin de mieux connâtre la structure changeante du marché du

* I wish to acknowledge the Social Sciences and Humanities Research Council (S.S.H.R.C.) for financial support of this study. Funding for the Transitions from School to Work Study was also provided by the S.S.H.R.C., the Alberta and Ontario governments, and the University of Alberta. I am grateful to Harvey Krahn and Graham Lowe for their comments on various drafts of this paper.

$\dagger$ Athabasca University, Faculty of Administrative Studies. 
travail et des opportunités d'emploi, ainsi que les rapports existant entre les diplômes et les exigences professionnelles. Suite aux préoccupations récentes concernant les pénuries de main-d'oeuvre, on reproche au système éducatif de mal préparer les jeunes à la vie professionnelle. Pourtant, il se pourrait que les carences perçues soient surtout attribuables à une mauvaise exploitation des compétences, auquel cas il serait plus approprié d'axer les mesures d'intervention sur les employeurs.

\section{Introduction}

Education-job mismatch is a form of underemployment which occurs when a job requires lower educational qualifications than those possessed by the worker. This paper examines data from a survey of 1985 Canadian university graduates, over one-third of whom were underemployed in this way two years after graduating with bachelor degrees in hand. As we rapidly shift toward the so-called information society where knowledge workers are supposedly in high demand, why are so many of our university graduates underemployed? Through detailed analysis of panel data, this paper raises serious doubts about the level of skills utilization among university graduates and formulates some concrete suggestions for improving the education-job matching process.

Concerns about underemployment and over-education have surfaced periodically over the past few decades (Anisef et al., 1980; Berg, 1970; Clogg \& Sullivan 1983; Freeman, 1976; Harvey, 1974; Mills, 1956; Rumberger, 1981; Smith 1986). The issue came to the forefront during the 1970 s as the babyboom generation descended upon the post-secondary education systems in Britain, Europe and North America. High unemployment rates and stories of graduates driving taxis were viewed as evidence that policies to expand access to higher education, prevalent during the 1960 s, had led to an oversupply of graduates. The value of higher education was questioned in terms of both the public and private benefits (Anisef \& Axelrod, 1993).

Expansion of higher education was one of many factors contributing to declining job prospects for graduates. Generational crowding, major economic recession, restructuring of the global economy and technological developments also affected the structure of labour market opportunity for young people. Employers, too, bore a portion of the blame for inflating job entry requirements and failing to invest sufficiently in training (Berg, 1970; Sullivan, 1978). There were predictions about widespread disenchantment and political instability as many young people saw their hopes and expectations unfulfilled (Blumberg \& Murtha, 1977; Guzzardi, 1976). Yet by the mid-1980s, in the wake of another 
major recession, many of these predictions had failed to materialize. Young people simply adjusted by going back to school, working their way into more suitable jobs, or changing their expectations (Krahn \& Lowe, 1993; Smith, 1986).

Reviewing research on higher education and work in Europe, Teicher concludes that while problems of unemployment and underemployment persist, the consequences are far less severe and much more diffuse than originally anticipated (1989, pp. 241-243). In Canada, demand for higher education has been growing despite declining economic returns to graduates (Statistics Canada, 1990, p. 57; Vaillancourt et al., 1987). Young people with university degrees have maintained a relative labour market advantage even though more are entering jobs at the middle to low end of the occupational status and wage categories (Blakely \& Harvey, 1988; Myles et al., 1988). This has serious labour market implications for those with lesser education, since many will be forced into lower level jobs with few opportunities for advancement (Blossfeld, 1990, p. 165; Krahn, 1992; Smith, 1986, p. 95). There are also negative psychological and economic consequences for those graduates who are unable to find jobs commensurate with their level of education (Burris, B. 1983; Burris, V., 1983; Rumberger, 1987).

In the late 1980 s, government and industry representatives began to complain about skill shortages and the failure of the education system to prepare young people adequately for the labour market (Canada, 1989; Canadian Chamber of Commerce, 1988; Economic Council of Canada, 1992). That this should be its primary role is a matter of ongoing debate but, once again, the fit between the education system and the labour market is considered to be essential to economic progress (Gaskell, 1993; Newson \& Buchbinder, 1988). Less criticism has been directed toward employers who have done little to increase skills utilization among the existing work force. Few have implemented programs aimed at training new labour market entrants, retraining older workers, or making the work environment more hospitable for women and minority groups (Hudson Institute, 1991; Musynski \& Wolfe, 1989; Sharpe, 1990). This, coupled with persistent evidence of underemployment among university graduates and other segments of the labour force, suggests that employers may be facing less of a skills shortage than we are led to believe.

The larger study described in this paper examined some of the broader theoretical question underlying research on education-job mismatch. The fundamental sociological question is: who has access to preferred jobs and why? A second important theoretical questions is: does our education system provide 
the individual with a relatively equitable means for realizing human potential and social mobility? In other words, are job rewards for those with the same level of education reasonably equitable? This paper highlights a third question more directly related to the labour market and human resources development: to what extent do we utilize the skills and abilities of those with higher education credentials? This latter question, although integrally linked with the first two, is particularly relevant today as our social and economic structures undergo dramatic changes and the education system comes under increased scrutiny.

With these broader theoretical issues in mind, three specific empirical questions are pursued in this paper: 1) what percentage of graduates were mismatched after two years in the labour force? 2) to what extent did mismatch vary by faculty, labour market location, gender and type of measure used? and 3) what are the theoretical and policy implications of these findings related to questions of equity, labour market opportunity and skills utilization?

Discussion of the panel data used in this study is preceded by a brief literature review of the research on education-job mismatch and changing job skill requirements. Both areas of inquiry are highly relevant to current concerns about skills mismatch.

\section{Education-Job Mismatch and The Skilling Debate}

Futurists such as Alvin Toffler explain that as technology replaces most of the manual jobs in the economy, the vast majority of workers spend their time "generating, getting or giving out information" (Toffler, 1990, p. 73). The information or post-industrial society thus requires cognitive rather than manual skills, and educated "knowledge workers" are presumed to be in high demand (Bell, 1973; Myles, 1988; Reich, 1991). The less optimistic scenario, put forth by Braverman (1974) and Edwards (1979), argues that technology is used to exert greater control over the labour process resulting in the gradual de-skilling of both the manual and cognitive aspects of work. From this perspective, deskilling and presumably underemployment are an inevitable result of the development of monopoly capitalism.

Similarly, de-industrialization theorists argue that growth in service sector employment will create a mass of unskilled, low-paying, part-time jobs with few benefits and little security (Bluestone \& Harrison, 1982). It is argued that this will result in a declining middle class as fewer workers are able to access higher income and higher status jobs (Kuttner, 1983). In Canada, there is evidence of increasing polarization in the distribution of job skill requirements within the service sector (Myles, 1988) and a relative decline in the proportion 
of middle-level skill jobs as a result of the general shift toward service sector employment (Economic Council of Canada, 1990, p. 14).

Empirical research, however, has produced little evidence of overall longterm de-skilling nor has it confirmed the more optimistic predictions of the post-industrial thesis. At the aggregate level of analysis, it seems more likely that a trend toward upgrading of skills in certain industrial sectors has been offset by considerable downgrading in others, resulting in little net change in skill levels of work over the past 50 years (Hunter, 1988; Myles, 1988; Spenner, 1983). For example, a recent trend toward skill upgrading in the female labour force is counterbalanced by a decline or stabilization of skill levels in occupations held by males (Boyd, 1990).

The concept of 'technical rationality' implied by structural functionalism and human capital theory underlies debates about skill requirements and education-job mismatch. Both assume that demand for certain education credentials is based on a need for specific skills. Individuals who invest in education and training to acquire such skills will have greater success in the labour market (Becker, 1964). Underemployment results when the supply of individuals possessing these skills exceeds demand. Thus, jobs requiring such skills are devalued and new entrants with previously marketable credentials find themselves unable to obtain the jobs they expected.

Critical social theorists such as Parkin (1979) and Collins (1979) question the extent to which employers match the skills and qualifications of job applicants to the skills requirements of work tasks. First of all, credentials and other selection criteria can act as barriers to occupational entry thereby preserving the interests of those who have traditionally held access to such positions (Collins, 1979). Hence, it is important to recognize the socially constructed aspects of skill, particularly how gender and class influence the way skill requirements are determined, valued, and rewarded (Jones, 1980; Livingstone, 1987).

Secondly, adoption of new technologies does not necessarily lead to higher skill requirements. It is becoming increasingly apparent that skills may be enhanced or diminished depending on how technology is implemented as part of the overall managerial strategy (Child, 1988; Mansell, 1987). The need for more educated workers refers to the importance of continuing education and retraining in order to adapt to technological change (Canada, 1989, pp. 19-20; Musynski \& Wolfe, 1989). Research on changing job skill requirements indicates that education policies should target those with low levels of schooling rather than vocationalizing post-secondary education programs (Spenner, 1988, p. 171). Emphasizing specific over general skill development may limit the 
capacity of workers to adapt to new systems or perform a variety of tasks (pp. 171-72).

Finally, the concept of skill is highly complex. Social scientists have only begun to identify the various dimensions of skill and new methodologies for measurement (Spenner, 1988, pp. 140-41). Few organizations have sophisticated job analysis processes or skills inventories in place. Hence, they often underestimate their own internal capacity for skills utilization and development.

According to some labour market analysts, the gap between job skill requirements and the skills and abilities of the work force is to a large extent a reflection of inadequacies in labour market processes which match people to jobs (Granovetter \& Tilley, 1988; Green \& Ashton, 1991). Hence, the focus should be less on what is wrong with the education system and more on "raising the level and broadening the range of skills actually used in the economy" (Green \& Ashton, 1991, p. 9). This requires ongoing monitoring of the match between job skill requirements and the skills capacity of the labour force. It also demands serious policy initiatives toward making effective use of our existing human resources.

Although the research results presented in this article can hardly begin to test some of these larger theoretical questions, they do lead to viable conclusions about the causes of mismatch and raise serious doubts about the degree of skills utilization in the existing pool of graduates.

\section{Research Data and Methods}

The data for this research were drawn from a larger set of survey data on high school and university graduates from three Canadian cities. The Study of Transitions from School to Work (Krahn, 1988; Krahn \& Lowe, 1990a, 1990b) is an ongoing longitudinal panel study designed to provide detailed information on schooling and labour market outcomes for a group of 1985 graduates.

Longitudinal data are critical to understanding how and why some graduates become underemployed while others do not. Many studies of underemployment use cross-sectional, aggregate data while the Transitions from School to Work study offers more detailed insight into the matching process. These data contain complete work histories along with changes in employment status so that labour market progression can be traced accurately. They also provide an opportunity to follow graduates entering distinctly different urban labour markets in the mid to late 1980s (Krahn \& Lowe, 1990a, 1990b). 
The study of underemployment consists of a smaller sample $(n=487)$ drawn from the 875 university graduates who responded to Transitions from School to Work survey in 1985, 1986 and 1987 . At the time this study was initiated, scant data were available on this particular graduate cohort. Since then, the National Graduates Surveys have collected longer-term follow-up data on 1982 and 1986 graduates (Clark, 1991a, 1991b).

University respondents in the Transitions from School to Work survey were undergraduates from the universities of Alberta and Toronto.' Questionnaires were distributed by mail to a systematically selected sample (every third name on the list of graduands) of Education, Engineering, Science, Arts and Business. ${ }^{2}$ Further sample selection was necessary to eliminate graduates who went on to obtain additional education credentials. Thus, only those with a bachelor level degree, who did not continue their education for more than two months full-time or part-time between 1985 and 1987, remained part of the sample. Over $90 \%$ of these respondents were employed full-time in 1987.

A key advantage of these data was the ability to construct and compare different measures of mismatch. Two self-reported measures were used: "My job lets me use my skills and abilities" and "My job lets me use my education and training" (strongly agree $=5$, strongly disagree $=1$ ). These questions are generally used as indicators of specific and general skill utilization (Denton et al., 1987). An alternative measure, one used in previous studies of mismatch, was also used. A General Educational Development score, one of several worker trait data included in the Canadian Classification and Dictionary of Occupations (C.C.D.O.), was assigned to each 4 digit occupation code (Canada, 1971).

The G.E.D. scores (1-6) represent six different levels of reasoning ability, knowledge, and skills in mathematics and language usually required to perform various occupational tasks (Canada, 1971, pp. 1161-2). A G.E.D. score of 5 equates to an occupational requirement for 16 years of schooling (Canada, 1988). Hence, a new dichotomous variable was created with values of $0=$ mismatched (job G.E.D. score was lower than 5) and 1=matched (job G.E.D. score was 5 or 6). Each case was coded as a 1 or 0 for occupations reported by these graduates in May 1986 and again in May 1987. ${ }^{3}$ This allowed for a categorization of match status based on reasonably objective criteria, something which most other Canadian studies have not done.

Mismatched graduates, then, are those who occupied jobs not requiring the level of education they had acquired through formal schooling (i.e., they were in jobs which could be performed by those without a university education). Matched graduates occupy jobs which require a level of educational development usually acquired through 16 or more years of education (the equivalent of 
a bachelor's level degree or higher). The measure of match status, then, does not reflect the extent to which graduates are overqualified or underemployed, but only whether they are in one or the other category.

The decision to use the G.E.D. method was made after considering the various alternatives and the kinds of questions this research intended to pursue. In the absence of more direct measures of skill, the G.E.D. score is the best available and most frequently used measure of job skill requirements (Clogg \& Shockey, 1984, p. 239; Spenner, 1980, p. 258; 1988, p. 140). The scale correlates well with self-reported measures of skill utilization and with other indicators of job complexity and occupational prestige (Hunter \& Manley, 1986; Jones, 1980; Myles \& Fawcett, 1990). Since levels of job skill requirements were determined by third-party job analysts, at least some of the biases of job occupants and employers are removed.

The validity of self-reported measures is often questioned because variables such as age, experience and gender have been shown to influence individual evaluations of mismatch (Burris, V., 1983, p. 457). Generally, these measures are thought to result in inflated estimates of underemployment compared to more objective methods (Clogg \& Shockey, 1984, p. 240). However, there are empirical data demonstrating that employees' perceptions of skill under-utilization are fairly good indicators of objective skill deficiencies in the job (O'Brien, 1986, pp. 40-46). Using both the G.E.D. and self-reported measures of skill utilization allows for the validity of the later to be gauged.

Underemployment, and mismatch in particular, is a difficult concept to define and measure (Clogg \& Shockey, 1984; Glyde, 1977; Sullivan, 1978; Teichler, 1989). Part of the difficulty is that we know little about the nature of skill and how to define it. Skills reside in the individual as well as in the job, and performance contributes to the way skills are utilized by organizations (O'Brien, 1986; Spenner, 1988). As stated earlier, there are also profound social biases (gender) and power relationships (unions, professional organizations) affecting the way skills are valued and rewarded in society (Livingstone, 1987). In short, job skill requirements are not strictly determined by the nature of the tasks to be done or the technology used to perform different tasks. Yet this assumption is part of the technical rationality thesis involved in human capital and status attainment theory (Jones, 1985).

\section{Rates of Mismatch and Skill Utilization}

This study finds that $35 \%$ of a group of respondents, with bachelor level degrees from the Universities of Alberta and Toronto, were employed in jobs 
Table 1

Education-job match status in 1987. by faculty of Graduation in 1985

\% MISMATCHED

ARTS

BUSINESS

EDUCATION

ENGINEERING

SCIENCE

TOTAL
* 69.4

32.9

10.4

16.9

45.2

34.6
TOTAL N

111

73

135

65

73

457

* Differences between faculties are statistically significant ( $\mathrm{p}<.01$, Chi-square test).

not requiring their level of educational attainment two years after graduating in 1985 (see Table 1). The overall rate of mismatch (39\% in 1986) declined, but not dramatically, over the two year survey period.

As Table 1 shows, rates of mismatch were predictably highest among Arts graduates $(70 \%)$, while few graduates from Education or Engineering were unable to find jobs related to their degrees. Surprisingly, $45 \%$ of the Science graduates in this study were working in jobs that did not require this level of education, while $34 \%$ of Business graduates were found to be educationally underemployed (see Table 1). The overall rate of mismatch increased to 56\% when graduates from the two professional degree programs (Education and Engineering) were excluded from the sample. The percentage of mismatched females was slightly higher than the percentage for mismatched males (37\% vs. $32 \%$ ) but differences were statistically non-significant ( $p>05$, Chi-square test).

Cross-tabular analysis demonstrates a very strong and significant relationship between the subjective measures of skill utilization and the G.E.D. measure of skills mismatch (see Table 2). Close to $60 \%$ of graduates who were mismatched according to the G.E.D. score disagreed with the statement that their jobs allowed them to utilize their skills and abilities while $79 \%$ of these graduates said their jobs were unrelated to their education and training. This differs from a study of 1970 s Ontario graduates, which found that G.E.D. measures were lower than subjective assessments of underemployment for men, but were more closely aligned to women's perceptions (Anisef et al., 1980).

Findings from this study cannot be generalized to the population of graduates as a whole. However, since the sample does include respondents from two of Canada's largest universities, including graduates from all major 
Table 2

Comparing objective and subjective measures of mismatch

\begin{tabular}{ccc}
$\begin{array}{c}\text { JOB } \\
<5\end{array}$ & G.E.D. SCORE & TOTAL N \\
\hline
\end{tabular}

The job lets me use my

skills \& abilities

$\%$ disagreeing.

The job is directly related to

my education and training

\% disagreeing

* 77.8

19.1

39.4

$(\mathrm{n}=180)$

* Relationships between the objective and subjective measures are statistically signifi cant ( $\mathrm{p}<.01$, Chi-square test).

undergraduate faculties, cautious generalization would be acceptable. The important question is, does one interpret these rates as being high or low? Compared to the labour force as a whole, graduates in this study experienced a higher rate of mismatch than the employed population with the same level of educational attainment. ${ }^{4}$ Although it is difficult to compare results from other studies due to variations in time, sampling, and types of measures used, these rates are similar to those obtained through the National Graduate Surveys and other surveys of Canadian graduates during the same time period (Clark et al., 1986, p. 7; Denton et al., 1987, p. 202). The 1988 National Graduate Survey of 1986 graduates reported that $36 \%$ of respondents at the bachelor's level said their jobs required less than an undergraduate degree. According to the same indicator 32\% of 1982 bachelor degree graduates were mismatched in 1984 (Clark, 1991b, p. 64). A longitudinal study of Ontario graduates using the G.E.D. and other measures of underemployment, reported a higher rate of mismatch ( $42 \%$ for men and $56 \%$ for women) for a university cohort entering the labour market in the late 1970s (Anisef et al., 1980, p. 234).

In sum, the rate of mismatch is an indicator that must be assessed on a comparative basis over time. Although longer term data have only recently been collected, there is evidence that the rate of mismatch declines as graduates gain more experience in the labour market (Clark, 1991a, p. 81; Krahn \& Lowe, 
1993, p. 91). It may take a period of five years, however, before the rate of mismatch for graduates parallels the rate for the population as a whole.

Results from this study highlight the importance of monitoring educationjob mismatch in addition to traditional labour market indicators, such as the unemployment rate. Interestingly, local labour market conditions had no significant effect on the probability of match or mismatch. In fact, the percentage of mismatched graduates working in cities with an unemployment rate of $8 \%$ and higher (in May, 1987) was slightly less than the percentage of mismatched graduates working in locations where unemployment rates were low (30.4\% vs. $36.3 \%, \mathrm{p}>.05$, Chi-square test). Approximately $40 \%$ of the graduates working in Toronto were mismatched at a time when the city was in the midst of an economic 'boom'. Hence, these data support the proposition that underemployment can co-exist with a high demand for labour (Blakely \& Harvey, 1988, p. 36; Sullivan, 1978, pp. 1-12).

The persistence of mismatch among these graduates also tends to support the proposition that changing demographic factors and cyclical economic conditions are not likely to eradicate the problem (Rumberger, 1981; Smith, 1986). Concurrent research analyzing data on 1976, 1982 and 1986 Canadian college and university graduates concluded that the smaller, post-recession cohort fared no better than larger cohorts who preceded them in the midst of recession (Davies et al., 1991). Ultimately, one has to assess education-job mismatch and the skills shortage scenario in the broader context of changing job skill requirements, increasing levels of educational attainment, and varying hiring standards for occupational entry. Greater emphasis must be placed on examining the structure of labour market opportunities and identifying barriers to effective skill utilization.

A closer look at these data suggests where some of these barriers might exist. First of all, it is interesting to note where graduates' perceptions of skill utilization differed from the G.E.D. measure of mismatch. Self-reported mismatch varied significantly by faculty (see Table 3 ) while gender differences were non-significant. But graduates from Education, Engineering and Business (the professional faculties) rated the education-job mismatch somewhat more critically on the subjective measures while Arts and Science graduates evaluated match more positively compared to their objectively measured rate.

For example, although $69 \%$ of the Arts graduates were mismatched according to G.E.D. scores, only 51\% thought their jobs did not allow them to use their skills and abilities (comparison between Table 1 and Table 3). On the other hand, $44 \%$ of Business graduates said their jobs did not utilize their skills 
Table 3

Subjective perceptions of skill utilization by faculty, 1987

\begin{tabular}{|c|c|c|c|c|}
\hline & $\begin{array}{l}\text { THE JOB LF } \\
\text { MY SKILLS }\end{array}$ & $\begin{array}{l}\text { S ME USE } \\
\text { ABILITIES }\end{array}$ & $\begin{array}{l}\text { THE JOB I } \\
\text { RELATE } \\
\text { EDUCATION }\end{array}$ & $\begin{array}{l}\text { IRECTLY } \\
\text { TO MY } \\
\text { TRAINING }\end{array}$ \\
\hline & \% Disagree & Total (n) & \% Disagree & Total (n) \\
\hline ARTS & * 51.4 & (111) & 65.2 & (112) \\
\hline BUSINESS & 44.4 & (72) & 43.1 & (72) \\
\hline EDUCATION & 20.7 & (135) & 15.6 & (135) \\
\hline ENGINEERING & 35.4 & $(65)$ & 36.9 & $(65)$ \\
\hline SCIENCE & 30.1 & (73) & 42.5 & (73) \\
\hline TOTAL & 35.5 & (456) & 39.4 & (457) \\
\hline
\end{tabular}

and abilities while only $33 \%$ were actually mismatched. Subjective underemployment was also greater than objective rates of mismatch for Education and Engineering graduates, although the majority of Education graduates (80-85\%) agreed with the statements about on-the-job skill utilization and relevance of training.

Again, the context in which respondents evaluate skills utilization is crucial. Two years after entering the labour market graduates are still in the early phase of their careers. Forty-one percent of the mismatched said chances for promotion from their present job were good (Redpath, 1991, p. 235). On the other hand, two years' labour market experience is sufficient to give young people a fairly solid grasp of what employers expect and a reasonable period of time to test out their skills and abilities.

The fact that $30-45 \%$ of graduates with so called 'applied' degrees in Business and Engineering say they were not using their knowledge, skills and abilities on the job may have important implications for theories of credentialism, the skilling debate and current policy discussions. Is there a legitimate basis for requiring a Business or Engineering degree for some of these jobs? Why are employers talking about severe skill shortages in these areas when graduates say they are not fully making use of their skills and abilities?

The data on mismatch by faculty raise other important questions. Is there a growing polarization in labour market opportunities for graduates with the same 
Table 4

Industrial sector by education-job mismatch, 1987

\begin{tabular}{|c|c|c|c|}
\hline & $\begin{array}{l}\% \text { DISTRIBUTION } \\
\text { OF MISMATCHED }\end{array}$ & $\begin{array}{c}\% \text { DISTRIBUTION } \\
\text { OF MATCHED }\end{array}$ & TOTAL $\mathbf{N}$ \\
\hline Goods producing & $* 17.7$ & 22.1 & 94 \\
\hline Distribution & 10.1 & 3.0 & 25 \\
\hline Consumer services & 26.6 & 2.3 & 49 \\
\hline Business services & 20.9 & 16.1 & 81 \\
\hline $\begin{array}{c}\text { Education, health \& } \\
\text { welfare services }\end{array}$ & \multicolumn{2}{|c|}{ Education, health \& } & 157 \\
\hline \multirow[t]{2}{*}{ Public administration } & 13.9 & 9.4 & 50 \\
\hline & 100.0 & 100.0 & 456 \\
\hline
\end{tabular}

level of post-secondary education? Is mismatch more likely to occur in certain industries? Are women with university degrees at no greater risk of being underutilized compared to their male contemporaries? The following sections examine data relevant to these questions.

\section{Industrial and Occupational Segmentation}

The industrial sector categories developed by Myles et al. (1988, p. 131) help locate the sources of 'good' and 'bad' jobs for this particular group of university graduates (See also Economic Council of Canada, 1990; Krahn, 1992; Krahn \& Lowe, 1990a). Forty-seven percent of the matched respondents (see Table 4) worked in education, health and welfare services while fewer were located in goods producing industries (22\%) and business services (16\%). ${ }^{5}$ Mismatched graduates were distributed across all industrial sectors with the largest proportion $(27 \%)$ located in consumer services industries (retail, food, accommodation, entertainment and personal services). However, underemployed graduates were also found in business services (21\%), the goods producing sector (18\%), and public administration (14\%). Education, health, and welfare, and distribution services hired fewer graduates into jobs not requiring a degree. 
Table 5

Occupational category by education-job mismatch, 1987

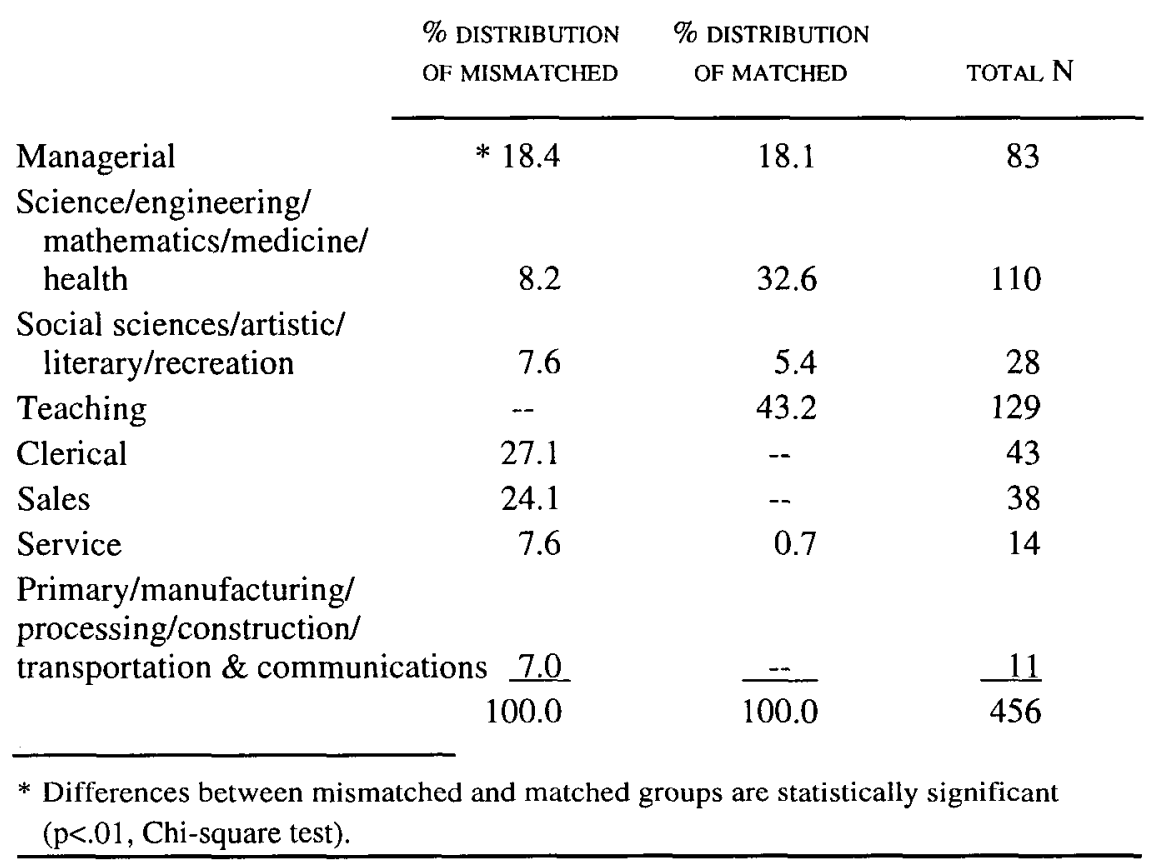

One could make a fairly accurate prediction of match or mismatch, then, by knowing that a respondent worked in the education, health and welfare service sector, or in consumer services. However, the goods producing, business services and public sector employment, usually noted as providing higher quality jobs compared to consumer services, also provided a substantial proportion of poorer quality jobs at least in terms of matching educational attainment with job requirements. ${ }^{6}$ A bifurcation in service sector jobs is evident, as Myles (1988, p. 346) suggests, but 'bad' jobs, in this case mismatched jobs, are spread across various sectors of the service and other industries.

Table 5 clearly shows that mismatched graduates entered different occupations than their matched counterparts. In 1987, nearly $60 \%$ of mismatched graduates were in clerical, sales and service occupations while the matched were working in professional jobs, primarily as teachers (43\%) or engineers $(31 \%)$. An equal proportion of both groups $(18 \%)$ was found in the managerial occupational category. Small numbers of mismatched graduates were scattered among 
various occupations whereas the matched were almost exclusively employed in professional, administrative or managerial jobs.

While only a handful of graduates were working as taxi drivers, labourers or waiting on tables, clerical and sales jobs were the leading occupations for mismatched graduates from all faculties followed by a small group in non-professional managerial (those who do not supervise professionals) or administrative jobs. Many high school or community college graduates aspire to these lower level clerical, sales, administrative and non-professional managerial jobs now filled by university graduates. A gradual encroachment of overqualified people in lower level occupations would inevitably force those with less schooling further down the occupational hierarchy (Krahn, 1992; Krahn \& Lowe, 1990a; Smith, 1986, p. 95). There is evidence that a considerable degree of vertical displacement has occurred (Blossfeld, 1990, p. 165; Teichler, 1989).

\section{Gender and Mismatch}

Though women graduates were no more likely to be mismatched compared to their male counterparts, gender emerges as a key variable in a more detailed examination of occupational outcomes. Mismatched women, many with Arts degrees, were highly concentrated in clerical jobs (38.4\%) whereas mismatched males were more likely to be found in sales jobs (30.4\%). Sales jobs for males were typically higher status, higher paying jobs such as sales supervisors or sales representatives, whereas the majority of female clerical jobs were lower level, non-supervisory positions such as typists, receptionists, electronic data processors, tellers, cashiers and retail sales clerks. These results reflect the willingness of employers to hire graduate women for low paying clerical work and the tendency for women to fall back on traditional "women's work" when they encounter barriers to accessing fast-track, higher paying, managerial and sales jobs. This is probably why women graduates in this study tended to be more severely underemployed in relation to the men. In all likelihood, mismatched women in clerical and low level retail sales jobs will find it difficult to move into matched jobs in the future.

Segregation also occurs in the matched group where $63 \%$ of the females were in teaching and related occupations compared to $19 \%$ of the males. Occupations in the social sciences (social work, psychology, personnel or industrial relations) were also more common among female graduates. Males were concentrated in engineering $(31 \%)$ or accounting $(18 \%)$ and were more prevalent in occupations related to the sciences, particularly geology and computing science. 
For the most part, this pattern results from gender differences in faculty of selection still influenced by traditional role modeling and the constrained choices women make in order to balance their career and personal lives (Jones et al., 1990). Studies tracking adolescents into career pathways indicate that even young women who do well in science subjects are aware that organizational and professional environments are inhospitable to women (Lewko, et al., 1993; Mandell \& Crysdale, 1993).

Pay inequity is one manifestation of this. Multiple regression analysis (not reported) on respondents in this study revealed that female graduates, regardless of match status, industrial sector location, or faculty of graduation, earned on average $\$ 39.00$ less per week than male graduates (Redpath, 1991, pp. 211213). These results confirm other findings that in spite of gains in educational attainment women continue to face discrimination in the way their skills are utilized and rewarded in the workplace (Hughes \& Lowe, 1993; Leiper \& Hunter, 1990; Wannell, 1990).

\section{Discussion}

For some, a bachelor degree signals entry into specific professional occupations while it merely puts others slightly ahead in the queue for jobs requiring a lower level of educational attainment. Evidently, the need for highly educated workers, predicted by post-industrialists and information society advocates, applies only to those with certain types of credentials. Hence, further research on labour market outcomes for graduates should monitor the degree of polarization in opportunities for graduates from different fields of study (Teichler, 1989, p. 227). Career tracks controlled by professional accreditation (Education, Engineering and Accounting) appear to offer the best prospects, at least for new graduates. If there are new opportunities in the service sector they are not necessarily providing opportunities for graduates to utilize their skills and abilities.

These data suggest that there are blatant discrepancies between the quantity and types of skilled workers employers say they need and the jobs graduates are actually obtaining. For example, while employers complain about a shortage of skilled scientists, $45 \%$ of the Science graduates in this study were underemployed, $42 \%$ said their jobs were not related to their education and training, and $30 \%$ reported that their skills and abilities were not being utilized on the job. ${ }^{7}$ It is unlikely that these results are entirely due to differences in the types of science courses taken by these graduates (e.g., life sciences versus physical sciences) and the kinds of scientific jobs available. If, as some employers say, there are serious deficiencies in course content then they must specify exactly 
where these deficiencies exist and how science courses could be made more job relevant. This would enable university curriculum planners and students interested in post-graduate career opportunities to design or choose course programs more closely aligned with labour market demand.

Further implications might be drawn from the fact that a significant proportion of Science graduates were either working at a technical level where their knowledge and training were underutilized, or working in jobs completely unrelated to their educational background. These graduates include those who studied computing science, mathematics, geology, biology, chemistry, zoology, physics and meteorology. In a society calling for development of greater scientific and technological expertise it seems incongruous to have so many science graduates underemployed. Again, the question arises: are employers making adequate use of the existing pool of graduates with science degrees? Furthermore, what kind and level of scientific knowledge do they actually require?

Improved information about job skill requirements is one way to address the problem of mismatch. Employers also have a responsibility to consider the transferability of knowledge and skills among various disciplines. This not only applies to Science graduates but to those from other faculties as well. For instance, employers may be underestimating the importance of a humanities or social science background in preparing young people for administrative and management roles (Rush \& Evers, 1986). Arts graduates are presumably equally as capable for many of the positions Business graduates occupy since many gain access to the same jobs. Management and administrative positions associated with staff functions such as accounting and finance, personnel or industrial relations, advertising, marketing purchasing, public relations and general administration were occupied by graduates in Business, Arts, and Science. Almost one third of the matched Arts graduates competed successfully with Business and Science graduates for jobs as financial or personnel managers or administrators, accountants and planners. While the majority of systems analysis or computer programming positions were filled by Science graduates, students from Business, Engineering, and Arts were also hired for these jobs.

The implications to be drawn from these observations are limited by the fact that employers' perspectives on job requirements and hiring practices were not the specific focus of inquiry in this study. However, it would be fair to question the tendency toward greater specialization and professionalization of postsecondary education programs when graduates from various faculties are capable of performing the same job functions. For example, unless a Business 
graduate goes on to article as a Chartered Accountant, he or she is likely to end up in a job similar to an Arts or Science graduate.

Business degrees are often preferred by employers for non-professional accounting or other financial and administrative jobs when, as these data indicate, graduates with other types of degrees are probably just as capable. Employer preferences for specific degrees are influenced by the prevailing corporate culture, the type of industry and the size of the firm doing the hiring (Useem, 1989, pp. 123-121). There are also mixed messages about hiring preferences within the firm. Executives and senior managers may be saying they want graduates with a broader liberal arts education background while the supervisors, managers or recruiters who do the hiring, continue to select graduates with specialized, technical degrees (Useem, 1989, pp. 130-134).

Universities are also responsible for reinforcing preferences for specialized degrees. They could do more to encourage employers to consider the various types of skills developed through different courses. Curriculum. requirements might also be relaxed by opening up boundaries between faculties and allowing students to take a broader range of courses. For example, Arts and Science students stand to benefit from a combined Business or Education degree. Conversely, Engineering or Business students might overcome some of their deficiencies in analytical and communication skills by strengthening the liberal arts component of their programs (Useem, 1989, p. 71).

In their study called "Making the Match" commissioned by the CorporateHigher Education Forum, Rush and Evers (1986) found that Arts graduates were better prepared in the areas of decision making, oral and written communication, interpersonal skills and managing conflict than were business and engineering students. In short, employers seek a combination of technical and non-technical skills acquired through both formal and informal educational preparation. Policies that emphasize technical curriculum content and specialized degrees based on occupational demand are not the answer to problems of mismatch or employer skill shortages.

\section{Conclusions}

Having a university degree is not sufficient to gain access to a job requiring the same level of educational attainment. Despite the present hue and cry over skilled labour shortages, there are only so many jobs available for young people with university degrees. Unless students choose a professional degree such as Education or Engineering, the chances of making a match are not much better than $50 \%$ (at least in the first few years after graduation). Even for these 
professions, long-term demand is difficult to predict; thus students who choose these degrees based on the success of preceding cohorts may find themselves underemployed.

A considerable number of graduates, particularly those with Arts degrees, are working in clerical, sales, and service jobs in the lower paying consumer services sector. Underemployed graduates are also found in the upper-tier of the services sector which includes professional and business services; education, health and welfare; and public administration (Krahn, 1992). Thus, continued growth in these sectors of the economy may not necessarily lead to greater demand for those with higher educational qualifications as the post-industrialists or information society theorists predict.

The matching of workers' skills and abilities with job requirements is a complex process where factors at the individual, organizational, institutional, and societal level influence the overall pattern of labour market outcomes (Baron \& Bielby, 1980; Granovetter \& Tilley, 1988). Results from this study suggest that the existing pool of graduates is probably better prepared for labour force entry than many employers assume. Surely, there are ways to improve the matching process and to achieve more effective utilization of the most educated segment of our labour force.

Employers claim that university graduates lack the kind of skills required in today's labour market (Canadian Chamber of Commerce, 1988, p. 29 and p. 38). If so, they must take the initiative to identify what specific skills are needed so that students can make more informed decisions when selecting courses and programs of study. Employers could also provide more on-the-job training to supplement knowledge and skills gained through general educational preparation. As mentioned earlier, there is good evidence that Canadian employers do little of this (Economic Council of Canada, 1992; Sharpe, 1990).

On the other hand, few universities have data on what happens to graduates once they enter the labour market, nor do they monitor levels of employer and graduate satisfaction (Anisef \& Axelrod, 1993, p. 113). We know that jobrelated reasons are an important factor in choosing a faculty of study; however, this does not mean that students desire a strictly vocationalized curriculum (Clark et al., 1986, p. 40; Krahn \& Lowe, 1990b, pp. 34-36). Ironically, courses in the social sciences and humanities are helping students to develop the very skills employers say are critical for today's managerial and professional jobs (Evers et al., 1991). Unfortunately, these skills are not formally recognized by employers or universities as being immediately job relevant. Furthermore, curriculum requirements often prevent student from crossing faculties to take job relevant courses. 
Toffler predicts that rather than technical skills, future employers will need a variety of cultural and interpersonal skills for jobs in the growing service sector - health care, child/elder care, personal, recreation services etc. $(1990$, p. 71$)$. The empirical evidence suggests there is greater uncertainty about the impact of information technology on job skill requirements (Spenner, 1988). Given this uncertainty, curriculum planners and employers have much to learn from monitoring the match between between the skills of university graduates and the skill requirements of their jobs.

This study reaffirms the need to continue to study gender biases and the way they inhibit optimal utilization of our human resources. Higher education, alone, will not resolve long-standing historical inequalities between men and women in the workplace (Boyd, 1990; Guppy et al., 1988; Hughes \& Lowe, 1993; Wannell, 1990). Women continue to choose Arts and Education degrees, which tend to lead them into occupations with lower pay and limited opportunities for promotion. Employers and educators must break this traditional pattern by doing more to attract and retain women in science, engineering, and other male dominated occupations. They also need to adopt equitable ways to evaluate the skills and abilities of graduates so that they are less reliant on the biases of managers and past organizational practices (Bills, 1988; Singh \& Crocker, 1988).

Underemployment persists even as Canada supposedly enters a decade of declining labour resources. There are serious long-term implications if present trends continue. Those faced with lower levels of educational attainment may find access to higher status clerical, administrative, and managerial jobs blocked by requirements for formal credentials, or by having to compete with university graduates for these jobs. By the same token, as an increasing proportion of university graduates return for further education, jobs previously accessible with a bachelor's degree (e.g., social worker, geologist, economist) may in future be obtained only by those with master's degrees. Hence, Randall Collins' (1979) vision of the credential society, in which formal educational requirements are raised to the point where they bear little relationship to technical job skill demands, may not be out of the realm of possibility. 


\section{Notes}

1 Graduates from Laurentian University in Sudbury were not included since their numbers were too small to make city to city comparisons.

2 Post-graduate faculties such as Law, Medicine and Dentistry were eliminated since they normally require a degree prior to entry and because their graduates move into highly regulated labour markets. Other faculties such as Nursing or Recreation Administration were omitted because of small enrollments. Since the primary purpose of the study was to examine youth labour market transitions, mature students (those over the age of 30 at the time of graduation) were also excluded from the sample.

3 Some judgement was required in assigning appropriate G.E.D. scores. For example, the occupation of accountant (CCDO code 1171) includes jobs such as branch accountants in banks, credit officers, and investment analysts (rated as G.E.D. 4) and accountants and auditors (rated as G.E.D. 5). The managerial and administrative group of occupations also varies in G.E.D. scores. The category of other managers (CCDO code 1149) for example, includes jobs such as manager of vehicles and equipment, restaurant managers, and administrative jobs which clearly do not require a university education. Additional information on job entry requirements was provided in Volume 2 of the C.C.D.O. Along with the researcher's knowledge and experience in job analysis, this information was used to determine if a university degree is normally required for a particular occupation.

${ }^{4}$ Using a self-reported measure, the 1989 General Social Survey indicates $22 \%$ of the working population with university degrees are overqualified for their jobs, almost identical to the rate of underemployment in the labour force as a whole (Krahn, 1982, pp. 111-112). Rates varied according to industrial sector location and type of employment. Using both the G.E.D. and self-reported measures, Myles and Fawcett (1990) found between 22 and $45 \%$ of a 1982-3 national sample of workers were underemployed, depending on the industrial sector where they worked.

5 In this section, cross-tabulation analysis is used to compare the percentage distribution of all mismatched graduates and all matched graduates working in each industrial sector and occupational category. A cross-tabulation of match status by industry provides an alternative perspective. For example, $90 \%$ of graduates working in education/health and welfare industries were matched while $86 \%$ of graduates working in consumer services were mismatched ( $\mathrm{p}<.05$, Chi-square test).

6 A recent report on non-standard work (self-employment, part-time, seasonal etc.) found significant pockets of this type of employment in some of the upper-tier service industries (Krahn, 1992).

7 Lowe and Krahn (1989) draw a similar conclusion suggesting that the supply of young graduates with computer skills may actually exceed existing demand. 


\section{References}

Anisef, P., \& Axelrod, P. (1993). Universities, graduates, and the marketplace: Canadian patterns and prospects. In P. Anisef \& P. Axelrod (eds.), Schooling and employment in Canada. Toronto: Thompson Educational Publishing.

Anisef, P., Paasche, J. Gottfried, \& Turritin, A.H. (1980). Is the die cast? Educational achievements and work destinations of Ontario youth. Toronto: Ministry of Colleges and Universities.

Baron, J.N., \& Bielby, W.T. (1980). Bringing the firms back in: Stratification, segmentation, and the organization of work. American Sociological Review, 45(5), 737-765.

Becker, G.S. (1964). Human capital. New York: Columbia University Press.

Bell, D. (1973). The coming of post-industrial society. New York: Basic Books.

Berg, I. (1970). Education and jobs: The great training robbery. New York: Praeger.

Bills, D.B. (1988). Credentials and capacities: Employers' perceptions of the aquisition of skills. The Sociological Quarterly, 29(3), 439-449.

Blakely, J.M., \& Harvey, E.B. (1988). Market and non-Market effects on male and female occupational status attainment. Canadian Review of Sociology and Anthropology (25)1, 238-40.

Blossfeld, M.P. (1990). Changes in educational careers in the Federal Republic of Germany. Sociology of Education (63), 165-177.

Bluestone, B., \& Harrison, B. (1982). The deindustrialization of America. New York: Basic Books.

Blumberg, P., \& Murtha, J.M. (1977). College graduates and the American dream. Dissent (24), 45-53.

Braverman, H. (1974). Labor and monopoly capital: The degradation of work in the twentieth century. New York: Monthly Review Press.

Boyd, M. (1990). Sex differences in occupational skill: Canada 1961-1986. Canadian Review of Sociology and Anthropology, 29(3), 285-315.

Burris, B.H. (1983). The human effects of underemployment. Social Problems, 3I(1), 96-110.

Burris, V. (1983). The social and political consequences of over-education. American Sociological Review, (48), 454-67.

Canada. (1971). Canadian classification and dictionary of occupations, Vols. 1 \& 2. Ottawa: Employment and Immigration Canada.

Canada. (1988). The C.C.D.O. Guide, 1988. Ottawa: Employment and Immigration Canada.

Canada. (1989). Success in the works: A profile of Canada's emerging work force. Ottawa: Employment and Immigration Canada.

Canadian Chamber of Commerce. (1988). Focus 2000. Report on the task force on harnessing change.

Child, J. (1988). Managerial strategies, new technology and the labour process. In R.E. Pahl (ed.), On work. Historical comparative theoretical approaches. New York: Basil Blackwell.

Clark, W. (1991a). The class of ' 82 revisited. Ottawa: Employment and Immigration Canada. 
Clark, W. (1991b). The class of 1986. Ottawa: Employment and Immigration Canada.

Clark, W., \& Zsigmond, Z. (1981). Job market reality for postsecondary graduates. Employment outcome by 1978, two years after Graduation. Catalogue 81-572E. Ottawa: Statistics Canada.

Clark, W., Laing, M., \& Rechnitzer, E. (1986). The class of 82. Summary report on the findings of the 1984 national survey of the graduates of 1982. Ottawa: Secretary of State and Statistics Canada.

Clogg, C.C., \& Sullivan, T. (1983). Labor force composition and underemployment trends, 1969-1980. Social Indicators Research, (12), 117-152.

Clogg, C.C., \& Shockey, J. W. (1984). Mismatch between occupation and schooling: A prevalence measure, recent trends and demographic analysis. Demography, 2I(2), 235-257.

Collins, R. (1979). The credential society. New York: Academic Press.

Davies, S., O'Grady, B., \& Mosher, C. (1991). Exploring trends in the transition from education to employment of Canadian postsecondary graduates. Paper presented at the Annual Meetings of the Canadian Sociology and Anthropology Association, Kingston, Ontario.

Denton, M.A., Davis, C.K., Hayward, L., \& Hunter, A.A. (1987). Employment survey of 1985 graduates of Ontario universities: Report of major findings. Toronto: Ontario Ministry of Education \& Ministry of Colleges and Universities.

Economic Council of Canada. (1990). Good jobs, bad jobs. Employment in the service economy. Ottawa: Supply and Services Canada.

Economic Council of Canada. (1992). A lot to learn. Education and training in Canada. Ottawa: Supply and Services Canada.

Edwards, R.C. (1979). Contested terrain: The transformation of the workplace in the twentieth century. New York: Basic Books.

Evers, F.T., Rush, J.C., \& Krmpotic, J. (1991). Skill competence development during the transition from university to work. Paper presented at the Canadian Sociology and Anthropology Association Meeting, Queen's University Kingston, Ontario.

Folger, J.K., \& Nam, C.B. (1964). Trends in education in relation to the occupational structure. Sociology of Education, (8), 19-33.

Freeman, R.B. (1976). The overeducated American. New York: Academic Press.

Gaskell, J. (1993). Introduction. In P. Anisef \& P. Axelrod (eds.), Schooling and employment in Canada. Toronto: Thompson Educational Publishing.

Glyde, G. (1977). Underemployment: Definition and causes. Journal of Economic Issues $X I(2), 245-260$.

Goyder, J.C. (1980). Trends in the socioeconomic achievement of the university educated: A status attainment model interpretation. The Canadian Journal of Higher Education, X(2), 21-38.

Granovetter, M., \& Tilley, C. (1988). Inequality and labor processes. In N.J. Smelser (ed.), Handbook of Sociology. Newbury Park, CA: Sage.

Green, F., \& Ashton, D. (1991). Skill shortage and skill deficiency: A critique. Discussion Paper No. 162, Centre for Labour Market Studies, University of Leicester. 
Guppy, N., Pendakur, K., \& Fenton, A. (1988). Changing patterns of stratification within higher education in the 1970s and 1980s. Paper presented at the 1988 meetings of the Western Association of Sociology and Anthropology, Edmonton, Alberta.

Guzzardi, W., Jr. (1976). The uncertain passage from college to job. Fortune (93), 126-129.

Harvey, E.B. (1974). Education systems and the labour market. Toronto: Longman.

Hudson Institute Canada. (1991). Work force 2000. Competing in a seller's market: Is Canadian management prepared? A survey report on organizational responses to demographic and labour force trends in Canada.

Hughes, K., \& Lowe, G.S. (1993). Unequal returns: Gender differences in initial employment among university graduates. Canadian Journal of Higher Education 23(1), 37-55.

Hunter, A.A. (1988). Formal education and initial employment: Unravelling the relationships between schooling and skills over time. American Sociological Review, 53(5), 753-765.

Hunter, A.A., \& Manley, M.C. (1986). On the task content of work. Canadian Review of Sociology and Anthropology, 23(1), 47-71.

Jones, C., Marsden, L., \& Tepperman, L. (1990). Lives of their own. The individualization of women's lives. Toronto: Oxford University Press.

Jones, F.E. (1980). Skill as a dimension of occupational classification. Canadian Review of Sociology and Anthropology (17), 176-83.

Jones, F.E. (1985). Educational and occupational attainment. In M. Boyd, J. Goyder, F.E. Jones, M.A. McRoberts, P.C. Pineo \& J. Porter (eds.), Ascription and achievement: Studies in status attainment in Canada. Ottawa: Carleton University Press.

Krahn, H.J. (1988). A study of the transition from school to work in three Canadian cities: Research design, response rates and descriptive results. Population Research Laboratory, Department of Sociology, University of Alberta.

Krahn, H.J. (1992). Quality of work in the service sector. General Social Survey Analysis Series, Catalogue 11-612E, No. 6. Ottawa: Statistics Canada.

Krahn, H.J., \& Lowe, G.S. (1990a). Young workers in the service economy. Working Paper No. 14. Ottawa: Economic Council of Canada.

Krahn, H.J., \& Lowe, G.S. (1990b). The school to work transition in Edmonton, 1985. 1989. Final Research Report. Prepared for Alberta Education and Alberta Career Development and Employment. Population Research Laboratory, Department of Sociology, University of Alberta.

Krahn, H.J., \& Lowe, G.S. (1991). Transitions to work: Findings from a longitudinal study of high school and university graduates in three Canadian cities. In D. Ashton \& G.S. Lowe (eds.), Making their way: A comparative analysis of the relationship between education, training and the labour market in Canada and Britain. London: Open University Press.

Krahn, H.J., \& Lowe, G.S. (1993). The school to work transition in Edmonton, $1985-$ 1992. Final Research Report. Prepared for Alberta Advanced Education and Career Development. Population Research Laboratory, Department of Sociology, University of Alberta. 
Kuttner, R. (1983). The declining middle. Atlantic Monthly (July), 60-72.

Leiper, J.M., \& Hunter, A.A. (1990). The credentialism debate: Academic certification and income. Paper presented at the 25th Annual Meetings of the Canadian Sociology and Anthropology Association, Victoria, B.C.

Lewko, J., Hein, C., Garg, R., \& Tesson, G. (1993). Transitions of adolescents into science career pathways. In P. Anisef \& P. Axelrod (eds.), Schooling and employment in Canada. Toronto: Thompson Educational Publishing.

Livingstone, D.W. (1987). Job skills and schooling: A class analysis of entry requirements and underemployment. Canadian Journal of Education 12(1), 1-30.

Lowe, G.S., \& Krahn, H.J. (1989). Computer skills and use among graduates. Canadian Public Policy, XV(2), 175-188.

Mandell, N., \& Crysdale, S. (1993). Gender tracks: Male-female perceptions of homeschool-work transitions. In Paul Anisef \& Paul Axelrod (eds.), Schooling and employment in Canada. Toronto: Thompson Educational Publishing.

Mansell, J. (1987). Workplace innovation in Canada. Ottawa: Economic Council of Canada.

Mills, C.W. (1956). White collar. The American middle class. New York: Oxford Press.

Musynski, L., \& Wolfe, D.A. (1989). New technology and training: Lessons from abroad. Canadian Public Policy, (XV)3, 245-264.

Myles, J. (1988). The expanding middle: Some canadian evidence on the deskilling debate. Canadian Review of Sociology and Anthropology, (25), 335-64.

Myles, J., Picot, G., \& Wannell, T. (1988). The changing wage distribution of jobs, 1981-1986. The Labour Force, Cat. 85-138. Ottawa: Statistics Canada.

Myles, J., \& Fawcett, G. (1990). Job skills and the service economy. Working Paper No. 4. Ottawa: Economic Council of Canada.

Newson, J., \& Buchbinder, H. (1988). The university means business. Toronto: Garamond Press.

O'Brien, G.E. (1986). Psychology of work and employment. New York: John Wiley and Sons.

Organization for Economic Development and Co-operation. (1989). Educational attainment and the labour force. In Employment outlook, 47-83. Paris: O.E.C.D..

Parkin, F. (1979). Marxism and class theory: A bourgeois critique. London: Tavistock.

Redpath, L. (1991). The causes and consequences of education-job mismatch: A study of underemployment among Canadian university graduates, 1985-87. Unpublished Ph.D. Thesis, Department of Sociology, University of Alberta.

Reich, R. (1991). The work of nations. New York: Alfred A. Knopf.

Rumberger, R.W. (1981). Over-education in the U.S. labor market. New York: Praeger.

Rush, J.C., \& Evers. F.T. (1986). Making the match: Canada's university graduates and corporate employers. Montreal: Corporate-Higher Education Forum.

Rush, J.C., \& Evers. F.T. (1987). The impact of surplus schooling on productivity and earnings. The Journal of Human Resources, (XXII)1, 24-50.

Sharpe, A. (1990). Training the work force: A challenge facing Canada in the '90s, perspectives on labour and income. Winter, Catalogue 75-001E. Ottawa: Statistics Canada. 
Singh, J.B., \& Crocker, O. (1988). Operative and espoused personnel selection criteria of managers. Relations Industrielles, 43(1), 167-180.

Smith, H.L. (1986). Over-education and underemployment: An agnostic review. Sociology of Education, (59), 85-99.

Spenner, K. (1980). Occupational characteristics and classification systems: New uses of the dictionary of occupational titles in social research. Sociological Methods and Research, (9)2, 239-264.

Spenner, K. (1988). Technological change, skill requirements, and education. The case for uncertainty. In R. Cyert \& D.C. Mowery (eds.), The impact of technological change on employment and economic growth. Cambridge, Mass.:Ballinger.

Statistics Canada. (1990). Education in Canada. A statistical review 1988-89. Catalogue, 81-229. Ottawa: Supply and Services Canada.

Sullivan, T.A. (1978). Marginal workers, Marginal jobs: The underutilization of American workers. Austin: University of Texas Press.

Teichler, U. (1989). Research on higher education and work in Europe. European Journal of Education (24)3, 223-247.

Toffler, A. (1990). Power shift: Knowledge, wealth, and violence at the edge of the 21st century. New York: Bantam.

Useem, M. (1989). Liberal education and the corporation: The hiring and advancement of college graduates. New York: Aldine de Gruyter.

Vaillancourt, F., Carpentier, J., \& Henriques, 1. (1987). The returns to university schooling in Canada: A rejoinder. Canadian Public Policy XIII(3), 389-390.

Wannell, T. (1990). Male-female earnings gap among recent university graduates. Perspectives on labour and income, Summer, Catalogue 75-001E. Ottawa: Statistics Canada. 